\title{
APPLICATION OF 1-MCP ON APRICOTS AT DIFFERENT TEMPERATURES AND DAYS AFTER HARVEST
}

\author{
L.P.L NGUYEN ${ }^{a *}$, G. HitKA ${ }^{\mathrm{a}}$, T. ZsOM ${ }^{\mathrm{a}}$ and Z. KÓKAI ${ }^{\mathrm{a}}$ \\ ${ }^{a}$ Department of Postharvest Science and Sensory Evaluation, Faculty of Food Science, Szent István University, \\ H-1118 Budapest, Ménesi út 43-45. Hungary
}

(Received: 4 March 2016; accepted: 15 June 2016)

\begin{abstract}
The efficacy of 1-MCP on apricots at different treatment temperatures and days after harvest during 6 weeks of storage at $1^{\circ} \mathrm{C}$ was investigated. On the $1^{\text {st }}, 3^{\text {rd }}$, or $5^{\text {th }}$ day after harvest, fruit were treated with 1 -MCP at $1^{\circ} \mathrm{C}$ for 24 hours. In order to evaluate the effect of temperature, apricots were exposed to $1-\mathrm{MCP}$ at 1,10 , and $20^{\circ} \mathrm{C}$ (on the $1^{\text {st }}$ day after harvest). 1-MCP application reduced the ethylene and $\mathrm{CO}_{2}$ production and delayed softening. Fruit treated on the $1^{\text {st }}$ day after harvest presented the highest firmness at the end of the experiment. No significant effect of treatment temperatures on apricot quality was observed. The time period between harvest and 1-MCP application could be delayed until the $5^{\text {th }}$ day after harvest. Results showed that 1-MCP extended the storage life and maintained the overall quality of apricot during storage and shelf-life.
\end{abstract}

Keywords: apricot (Prunus armeniaca L.), 1-MCP, storage, temperature, delay

The highly appreciated and popular apricot's (Prunus armeniaca L.) fame is due to its attractive orange coloured appearance, unique flavour, and nutritional value (LECCESE et al., 2008). However, because of its short season and postharvest shelf-life, the time for transport, sale, and consumption is limited in time. The postharvest ripening process of apricot is relatively quick, so the quality marks of the fruit decrease significantly including wrinkled skin, flesh softening, reduced juiciness, and nutrition losses (Wu et al., 2015).

The efficacy of 1-methylcyclopropene (1-MCP) in maintaining fruit quality in case of tomato, apple, pear, plum, avocado, and melon (Blankenship \& Dole, 2003; HitKA et al., 2014) has been widely reported. However, in the commercial utilization strategy, exposure temperature and delays of treatment play an important role in close relation to the features of the different storage facilities. So, the aim of this study was to examine 1-MCP efficacy and response of the apricot to treatments at different days after harvest and different temperatures during cold storage and shelf-life.

\section{Materials and methods}

\subsection{Materials}

Fresh samples of 'Zebra' apricots (Prunus armeniaca L.) were harvested while at a light yellow colour by an experienced grower in July 2015, Hungary. Fruit were transported to the Faculty of Food Science of the Szent István University in Budapest, Hungary.

1-MCP (SmartFresh ${ }^{\circledR}$, AgroFresh, Philadelphia, USA) as an application of SmartFresh ${ }^{\circledR}$ system was provided by Rohm and Haas Polska Sp.z.o.o.

* To whom correspondence should be addressed.

Phone: +36-1-305-7662; fax: +36-1-305-7662; e-mail: coni_love@yahoo.com

0139-3006/\$20.00 C 2016 Akadémiai Kiadó, Budapest 


\subsection{1-MCP application}

Fruit were selected for uniformity of size, shape, and freedom from external damage. Samples were randomly divided into 8 groups: 6 treated groups and 2 untreated groups. Each group had one hundred and fifty fruit. All 6 groups were treated with 625-650 ppb gaseous 1-MCP (standard commercial application rate) for 24 hours in an air-tight plastic box.

1.2.1. Application of 1-MCP at different temperatures. Apricots were kept for 24 hours at 1,10 , and $20^{\circ} \mathrm{C}$ before treatment, and then three groups were treated with 1 -MCP at 1,10 , and $20^{\circ} \mathrm{C}$, respectively on the $1^{\text {st }}$ day after harvest.

1.2.2. Application of 1-MCP at different days after harvest. Fruit were stored at $1{ }^{\circ} \mathrm{C}$ before treatment. Three groups were treated with $1-\mathrm{MCP}$ on the $1^{\text {st }}, 3^{\text {rd }}$, and $5^{\text {th }}$ day after harvest (Table 1).

\begin{tabular}{lcccccc}
\multicolumn{7}{c}{ Table 1. Application of 1-MCP on different days after harvest } \\
\hline $\begin{array}{l}\text { Day } \\
\text { Sample }\end{array}$ & 0 (Harvest) & 1 & 2 & 3 & 4 & 5 \\
\hline $1^{\text {st }}$ & $\mathrm{C}$ & $\mathrm{T}$ & $\mathrm{C}$ & $\mathrm{C}$ & $\mathrm{C}$ & $\mathrm{C}$ \\
$3^{\text {rd }}$ & $\mathrm{C}$ & $\mathrm{C}$ & $\mathrm{C}$ & $\mathrm{T}$ & $\mathrm{C}$ & $\mathrm{C}$ \\
$5^{\text {th }}$ & $\mathrm{C}$ & $\mathrm{C}$ & $\mathrm{C}$ & $\mathrm{C}$ & $\mathrm{C}$ & $\mathrm{T}$ \\
Control & $\mathrm{C}$ & $\mathrm{C}$ & $\mathrm{C}$ & $\mathrm{C}$ & $\mathrm{C}$ & $\mathrm{C}$ \\
\hline
\end{tabular}

C: Cooling at $1{ }^{\circ} \mathrm{C}$; T: Treated with $1-\mathrm{MCP}, 24 \mathrm{~h}$ at $1{ }^{\circ} \mathrm{C}$

\subsection{Storage}

After 1-MCP application, treated fruit were kept at $1{ }^{\circ} \mathrm{C}$ and $\mathrm{RH} 90-95 \%$. The control group was stored at $1{ }^{\circ} \mathrm{C}$ and $\mathrm{RH} 90-95 \%$ for 42 days. Every two weeks 25 samples of each group were removed from the fridge for 1 week of shelf-life at $20^{\circ} \mathrm{C}$.

\subsection{Measurements}

Measurements were carried out on day $0,14^{\text {th }}, 28^{\text {th }}$, and $42^{\text {nd }}$ and at the end of each shelf-life after 2 and 4 weeks of storage period, respectively.

Before 1-MCP treatment, the ethylene production and respiration were measured at $20^{\circ} \mathrm{C}$ and $1{ }^{\circ} \mathrm{C}$. Later, these measurements were also carried out at $1{ }^{\circ} \mathrm{C}$ on the $14^{\text {th }}, 28^{\text {th }}$, and $42^{\text {nd }}$ day of storage. Finally, after removal from cold storage, ethylene and $\mathrm{CO}_{2}$ production were measured at $20^{\circ} \mathrm{C}$ at the end of each shelf-life period.

Acoustic firmness, surface colour, and soluble solid content were measured at $20{ }^{\circ} \mathrm{C}$ during the experiment.

1.4.1. Acoustic firmness. Acoustic firmness $\left(\mathrm{S}, \mathrm{Hz}^{2} \mathrm{~g}^{2 / 3}\right)$ of the samples was determined at two opposite sides on the exterior circumference of each fruit, using an Aweta table top acoustic firmness sensor model DTF V0.0.0.105 (Aweta, Nootdorp, The Netherlands). 
1.4.2. Ethylene production. Ethylene production was determined by an ICA-56 handheld ethylene analyzer (International Controlled Atmosphere Ltd., UK) upon the measured ethylene production of the samples being held for a given time (about an hour) in a hermetically closed plastic container. Results were expressed in microlitres of ethylene produced per kilogram of fruit in $1 \mathrm{~h}\left(\mu 1 \mathrm{~kg}^{-1} \mathrm{~h}^{-1}\right)$.

1.4.3. Respiration rate. Respiratory intensity as carbon dioxide production was measured for an hour in a closed respiratory system containing several hermetically closed plexi glass containers equipped with FY A600-CO2H carbon dioxide sensors connected to an Almemo 3290-8 data logger (Ahlborn Mess- und Regelungstechnik GmbH, Germany). Results were expressed in millilitres of $\mathrm{CO}_{2}$ produced per kilogram of fruit in $1 \mathrm{~h}\left(\mathrm{ml} \mathrm{kg}^{-1} \mathrm{~h}^{-1}\right)$.

1.4.4. Surface colour. Apricot peel colour was measured with a portable Minolta Chroma Meter CR-400 (Minolta Corporation, Osaka, Japan). CIE L*, a*, and b* colour characteristics were determined at two opposite points on the external circumference of each fruit. Hue angle $\left(\mathrm{H}^{\circ}\right)$ value was calculated as arctangent $(\mathrm{b} / \mathrm{a})$.

1.4.5. Soluble solid content. Soluble solid content (SSC, \%) was determined by a handheld temperature-compensated ATAGO PAL-1 digital refractometer (Atago Co. Ltd., Tokyo, Japan).

\subsection{Statistical analysis}

All data were processed by SPSS (SPSS Inc, USA) using analysis of variance (ANOVA) with the following factors: treatment temperatures $\left(1^{\circ} \mathrm{C}, 10^{\circ} \mathrm{C}\right.$, and $\left.20^{\circ} \mathrm{C}\right)$ and treatment day $\left(1^{\text {st }}\right.$, $3^{\text {rd }}$, and $5^{\text {th }}$ day), followed by Tukey's method with a significance level of $\mathrm{P}<0.05$. The results were reported as a mean with standard deviations ( $95 \%$ confidence interval).

\section{Results and discussion}

\subsection{Results}

2.1.1. 1-MCP application at different temperatures. Ethylene production of all samples increased during storage. Ethylene production of control group showed a sharp increase throughout cold storage and after shelf-life (Table 2). The respiration rate of all samples rose dramatically throughout the shelf-life period. Control fruit showed a much higher level of carbon dioxide production than treated fruit (Table 2). At the end of cold storage, the respiration rate of fruit treated at $1{ }^{\circ} \mathrm{C}$ was lower than others'. Differences in ethylene and $\mathrm{CO}_{2}$ production for fruit treated at different temperatures were minor during storage and shelf-life.

The firmness of treated apricots decreased gradually during the 6 weeks of storage at $1{ }^{\circ} \mathrm{C}$. In contrast, the softening of samples took place very quickly at $20^{\circ} \mathrm{C}$ during shelf-life (Table 2). The decline in acoustic firmness indicated that the mechanical texture of fruit changed throughout storage (Zsom-Muna \& FelföLdI, 2007). No significant effect of treatment temperatures was observed for firmness. However, storage period and storage temperature had a significant influence on firmness. 
Table 2. Quality of apricot treated at different temperatures during storage (at $1{ }^{\circ} \mathrm{C}$ ) and shelf-life (at $20{ }^{\circ} \mathrm{C}$ )

\begin{tabular}{|c|c|c|c|c|}
\hline Time & Samples & $\begin{array}{c}\text { Ethylene } \\
\left(\mu 1 \mathrm{~kg}^{-1} \mathrm{~h}^{-1}\right)\end{array}$ & $\begin{array}{l}\text { Respiration } \\
\left(\mathrm{ml} \mathrm{kg}^{-1} \mathrm{~h}^{-1}\right)\end{array}$ & $\begin{array}{c}\text { Firmness } \\
\left(10^{6} \mathrm{~Hz}^{2} \mathrm{~g}^{2 / 3}\right)\end{array}$ \\
\hline Initial & at $1{ }^{\circ} \mathrm{C}$ & $0.24 \pm 0.05$ & $4.5 \pm 0.6$ & $5.10 \pm 0.20$ \\
\hline \multirow[t]{4}{*}{$14 \mathrm{~d} \mathrm{ST}$} & Untreated & $0.50 \mathrm{a}$ & $9.1 \mathrm{a}$ & $2.30 \mathrm{a}$ \\
\hline & $1-\mathrm{MCP}_{1{ }^{\circ} \mathrm{C}}$ & $0.30 \mathrm{~b}$ & $5.8 \mathrm{~b}$ & $3.10 \mathrm{~b}$ \\
\hline & $1-\mathrm{MCP}_{10}{ }^{\circ} \mathrm{C}$ & $0.25 \mathrm{~b}$ & $5.4 \mathrm{~b}$ & $3.15 \mathrm{~b}$ \\
\hline & $1-\mathrm{MCP}_{20}{ }^{\circ} \mathrm{C}$ & $0.23 \mathrm{~b}$ & $4.7 \mathrm{~b}$ & $2.98 \mathrm{~b}$ \\
\hline \multirow[t]{4}{*}{$28 \mathrm{~d} \mathrm{ST}$} & Untreated & $1.11 \mathrm{a}$ & $11.1 \mathrm{a}$ & $1.31 \mathrm{a}$ \\
\hline & $1-\mathrm{MCP}_{1{ }^{\circ} \mathrm{C}}$ & $0.61 \mathrm{~b}$ & $8.2 \mathrm{~b}$ & $2.65 \mathrm{~b}$ \\
\hline & $1-\mathrm{MCP}_{10^{\circ} \mathrm{C}}$ & $0.43 \mathrm{~b}$ & $8.7 \mathrm{~b}$ & $2.70 \mathrm{~b}$ \\
\hline & $1-\mathrm{MCP}_{20{ }^{\circ} \mathrm{C}}$ & $0.52 \mathrm{~b}$ & $9.4 \mathrm{~b}$ & $2.45 \mathrm{~b}$ \\
\hline \multirow[t]{4}{*}{$42 \mathrm{~d} \mathrm{ST}$} & Untreated & $4.46 \mathrm{a}$ & $15.1 \mathrm{a}$ & $0.95 \mathrm{a}$ \\
\hline & $1-\mathrm{MCP}_{1{ }^{\circ} \mathrm{C}}$ & $0.74 \mathrm{~b}$ & $9.2 \mathrm{~b}$ & $1.85 \mathrm{~b}$ \\
\hline & $1-\mathrm{MCP}_{10^{\circ} \mathrm{C}}$ & $0.69 \mathrm{~b}$ & $11.9 \mathrm{~b}$ & $1.79 \mathrm{~b}$ \\
\hline & $1-\mathrm{MCP}_{20{ }^{\circ} \mathrm{C}}$ & $0.72 \mathrm{~b}$ & $11.7 \mathrm{~b}$ & $1.74 \mathrm{~b}$ \\
\hline Initial & at $20^{\circ} \mathrm{C}$ & $2.6 \pm 0.38$ & $31.4 \pm 2.5$ & $5.10 \pm 0.20$ \\
\hline \multirow[t]{4}{*}{$14 \mathrm{~d} \mathrm{ST}+7 \mathrm{~d} \mathrm{SL}$} & Untreated & $41.51 \mathrm{a}$ & $92.7 \mathrm{a}$ & $0.82 \mathrm{a}$ \\
\hline & $1-\mathrm{MCP}_{1{ }^{\circ} \mathrm{C}}$ & $3.72 \mathrm{~b}$ & $50.2 \mathrm{~b}$ & $1.45 \mathrm{~b}$ \\
\hline & $1-\mathrm{MCP}_{10{ }^{\circ} \mathrm{C}}$ & $3.33 \mathrm{~b}$ & $48.2 \mathrm{~b}$ & $1.39 \mathrm{~b}$ \\
\hline & $1-\mathrm{MCP}_{20^{\circ} \mathrm{C}}$ & $4.06 \mathrm{~b}$ & $47.7 \mathrm{~b}$ & $1.44 \mathrm{~b}$ \\
\hline \multirow[t]{4}{*}{$28 \mathrm{~d} \mathrm{ST}+7 \mathrm{~d} \mathrm{SL}$} & Untreated & $79.95 \mathrm{a}$ & $126.8 \mathrm{a}$ & $0.65 \mathrm{a}$ \\
\hline & $1-\mathrm{MCP}_{1{ }^{\circ} \mathrm{C}}$ & $33.72 \mathrm{~b}$ & $52.6 \mathrm{~b}$ & $1.24 \mathrm{~b}$ \\
\hline & $1-\mathrm{MCP}_{10{ }^{\circ} \mathrm{C}}$ & $35.38 \mathrm{~b}$ & $50.9 \mathrm{~b}$ & $1.22 \mathrm{~b}$ \\
\hline & $1-\mathrm{MCP}_{20}{ }^{\circ} \mathrm{C}$ & $34.03 \mathrm{~b}$ & $51.5 \mathrm{~b}$ & $1.30 \mathrm{~b}$ \\
\hline
\end{tabular}

$1-\mathrm{MCP}_{1,10 \text { and } 20{ }^{\circ} \mathrm{C}}: 1-\mathrm{MCP}$ application was carried out at 1,10 and $20{ }^{\circ} \mathrm{C}$, respectively. ST: storage at $1{ }^{\circ} \mathrm{C}$; SL: shelf-life at $20^{\circ} \mathrm{C}$. Means followed by the same letters are not significantly different at the same measurement time (Tukey's, $\mathrm{P}<0.05$ ).

During storage, the skin colour of the apricot turned from light yellow to orange. The colour change was often reported as a sign of ripening (Dong et al., 2002; KovÁcs et al., 2008). Hue angle value showed the same trend at different treatment temperatures (Fig. 1). At day 0 , the SSC was $11.1 \pm 0.45 \%$ and increased slightly at the end of experiment. No significant difference between treatment temperatures was detected for SSC values (Fig. 2). 


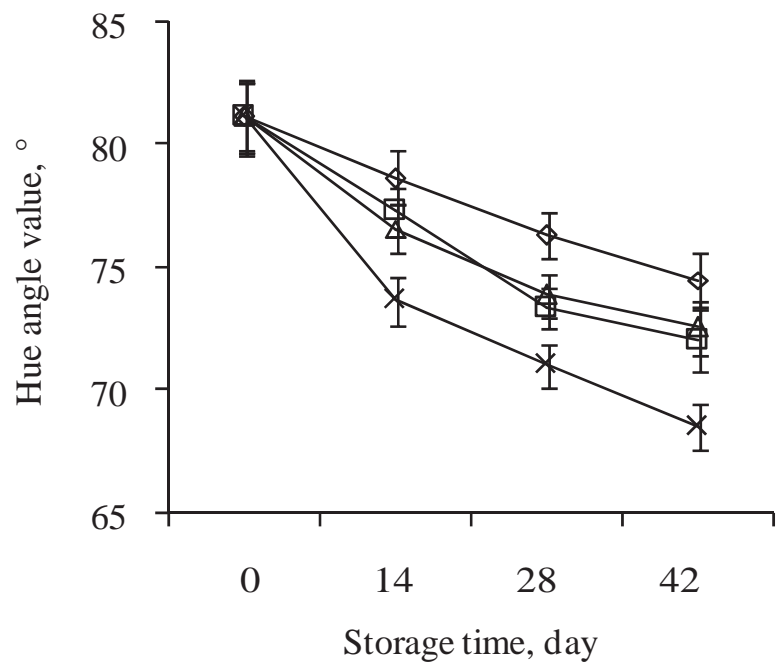

Fig. 1. Hue angle value of apricot treated at different temperatures during storage at $1{ }^{\circ} \mathrm{C}(\diamond): 1-\mathrm{MCP}_{1{ }^{\circ} \mathrm{C}} ; \square$ :

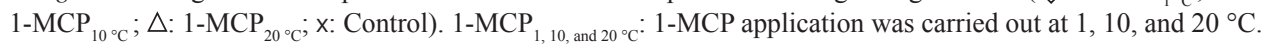
Values are the mean \pm SD

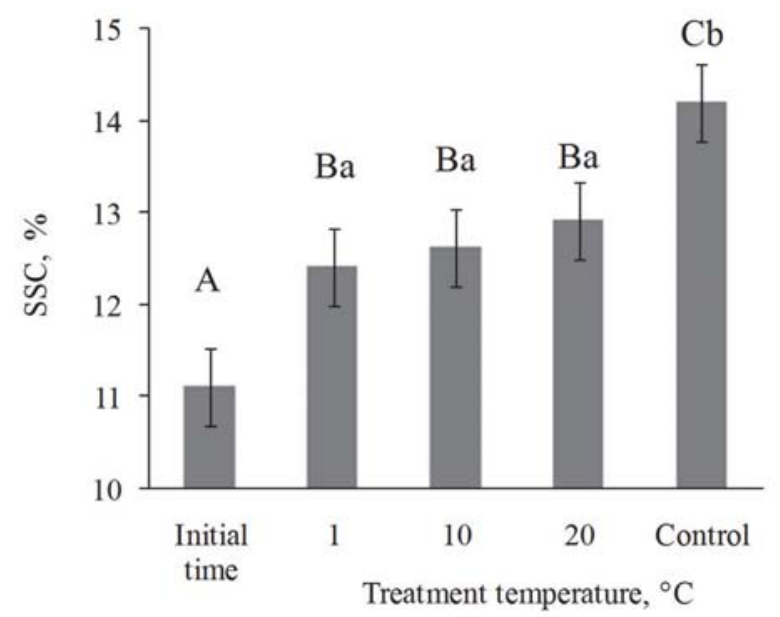

Fig. 2. Soluble solid content of apricot treated at different temperatures at $42^{\text {nd }}$ day. Values are the mean $\pm \mathrm{SD}$. Upper case is for the comparisons with initial value (Dunnett, $\mathrm{P}<0.05$ ). Lower case is for the comparisons of treatment temperatures (Tukey's, $\mathrm{P}<0.05$ ).

2.1.2. Application delays of 1-MCP after harvest. The ethylene and respiratory $\mathrm{CO}_{2}$ production of fruit rose as the storage period increased, but at different rates. Apricots treated on the $1^{\text {st }}$ day after harvest produced the lowest amount of ethylene and $\mathrm{CO}_{2}$ on the $42^{\text {nd }}$ day 
of the cold storage period (Table 3). Differences in firmness between fruit treated on the $1^{\text {st }}$, $3^{\text {rd }}$, and $5^{\text {th }}$ day after harvest were minor after 2 weeks of cold storage and shelf-life (Table 3 ). During the cold storage period, firmness of fruit declined gradually, but at $20{ }^{\circ} \mathrm{C}$ of shelf-life the softening of samples occurred rapidly (Table 3 ). Apricots treated on the $1^{\text {st }}$ day after harvest were firmer than the samples of other treatment days, but the firmness of samples treated on the $3^{\text {rd }}$ and $5^{\text {th }}$ day after harvest still remained high. No significant difference in ethylene, respiratory $\mathrm{CO}_{2}$ production, and firmness was detected between fruit treated on the $3^{\text {rd }}$ and $5^{\text {th }}$ day after harvest.

Table 3. Quality of apricot treated on different days after harvest during storage $\left(\right.$ at $1{ }^{\circ} \mathrm{C}$ ) and shelf-life (at $20^{\circ} \mathrm{C}$ )

\begin{tabular}{|c|c|c|c|c|}
\hline Time & Samples & $\begin{array}{c}\text { Ethylene } \\
\left(\mu 1 \mathrm{~kg}^{-1} \mathrm{~h}^{-1}\right)\end{array}$ & $\begin{array}{l}\text { Respiration } \\
\left(\mathrm{ml} \mathrm{kg}^{-1} \mathrm{~h}^{-1}\right)\end{array}$ & $\begin{array}{c}\text { Firmness } \\
\left(10^{6} \mathrm{~Hz}^{2} \mathrm{~g}^{2 / 3}\right)\end{array}$ \\
\hline Initial & at $1{ }^{\circ} \mathrm{C}$ & $0.24 \pm 0.05$ & $4.5 \pm 0.6$ & $5.10 \pm 0.20$ \\
\hline \multirow[t]{4}{*}{$14 \mathrm{~d}$ ST } & Untreated & $0.50 \mathrm{a}$ & $9.1 \mathrm{a}$ & $2.30 \mathrm{a}$ \\
\hline & $1-\mathrm{MCP}_{1 \mathrm{st}}$ & $0.30 \mathrm{~b}$ & $5.8 \mathrm{~b}$ & $3.10 \mathrm{~b}$ \\
\hline & $1-\mathrm{MCP}_{3 \mathrm{rd}}$ & $0.32 \mathrm{~b}$ & $6.7 \mathrm{~b}$ & $2.85 \mathrm{~b}$ \\
\hline & $1-\mathrm{MCP}_{5 \text { th }}$ & $0.35 \mathrm{~b}$ & $6.2 \mathrm{~b}$ & $2.50 \mathrm{~b}$ \\
\hline \multirow[t]{4}{*}{ 28d ST } & Untreated & $1.11 \mathrm{a}$ & $11.1 \mathrm{a}$ & $1.31 \mathrm{a}$ \\
\hline & $1-\mathrm{MCP}_{1 \mathrm{st}}$ & $0.61 \mathrm{~b}$ & $8.2 \mathrm{~b}$ & $2.65 \mathrm{~b}$ \\
\hline & $1-\mathrm{MCP}_{3 \mathrm{rd}}$ & $0.56 \mathrm{~b}$ & $8.1 \mathrm{~b}$ & $2.27 \mathrm{~b}$ \\
\hline & $1-\mathrm{MCP}_{5 \text { th }}$ & $0.68 \mathrm{~b}$ & $9.2 \mathrm{~b}$ & $2.04 \mathrm{~b}$ \\
\hline \multirow[t]{4}{*}{ 42d ST } & Untreated & $4.46 \mathrm{a}$ & $15.1 \mathrm{a}$ & $0.95 \mathrm{a}$ \\
\hline & $1-\mathrm{MCP}_{1 \mathrm{st}}$ & $0.74 \mathrm{~b}$ & $9.2 \mathrm{~b}$ & $1.85 \mathrm{~b}$ \\
\hline & $1-\mathrm{MCP}_{3 \mathrm{rd}}$ & $1.22 \mathrm{c}$ & $11.6 \mathrm{c}$ & $1.45 \mathrm{c}$ \\
\hline & $1-\mathrm{MCP}_{5 \text { th }}$ & $1.38 \mathrm{c}$ & $12.4 \mathrm{c}$ & $1.40 \mathrm{c}$ \\
\hline Initial & at $20^{\circ} \mathrm{C}$ & $2.6 \pm 0.38$ & $31.4 \pm 2.5$ & $5.10 \pm 0.20$ \\
\hline \multirow[t]{4}{*}{$14 \mathrm{~d} \mathrm{ST}+7 \mathrm{~d} \mathrm{SL}$} & Untreated & $41.51 \mathrm{a}$ & $92.7 \mathrm{a}$ & $0.82 \mathrm{a}$ \\
\hline & $1-\mathrm{MCP}_{1 \mathrm{st}}$ & $3.72 \mathrm{~b}$ & $50.2 \mathrm{~b}$ & $1.45 \mathrm{~b}$ \\
\hline & $1-\mathrm{MCP}_{3 \mathrm{rd}}$ & $5.34 \mathrm{c}$ & $63.0 \mathrm{c}$ & $1.06 \mathrm{c}$ \\
\hline & $1-\mathrm{MCP}_{5 \text { th }}$ & $7.95 \mathrm{c}$ & $64.6 \mathrm{c}$ & $1.08 \mathrm{c}$ \\
\hline \multirow[t]{4}{*}{$28 \mathrm{~d} \mathrm{ST}+7 \mathrm{~d} \mathrm{SL}$} & Untreated & $79.95 \mathrm{a}$ & $126.8 \mathrm{a}$ & $0.65 \mathrm{a}$ \\
\hline & $1-\mathrm{MCP}_{1 \mathrm{st}}$ & $33.72 \mathrm{~b}$ & $52.6 \mathrm{~b}$ & $1.24 \mathrm{~b}$ \\
\hline & $1-\mathrm{MCP}_{3 \mathrm{rd}}$ & $40.35 \mathrm{c}$ & $94.4 \mathrm{c}$ & $0.92 \mathrm{c}$ \\
\hline & $1-\mathrm{MCP}_{5 \text { th }}$ & $47.43 \mathrm{c}$ & $92.3 \mathrm{c}$ & $0.88 \mathrm{c}$ \\
\hline
\end{tabular}

$1-\mathrm{MCP}_{1 \mathrm{st}, 3 \mathrm{rd} \text { and 5th }}: 1-\mathrm{MCP}$ application was carried out at days 1,3 and 5 after harvest, respectively. ST: storage at $1{ }^{\circ} \mathrm{C}$; SL: shelf-life at $20^{\circ} \mathrm{C}$

Hue angle values of apricots treated on the $1^{\text {st }}$ day had a higher level than those of fruit treated on the $3^{\text {rd }}$ and $5^{\text {th }}$ day after harvest during the storage period. The skin of control fruit changed to orange much more rapidly than those of treated samples (Fig. 3). There was no significant effect of delays of treatment on SSC (Fig. 4). 


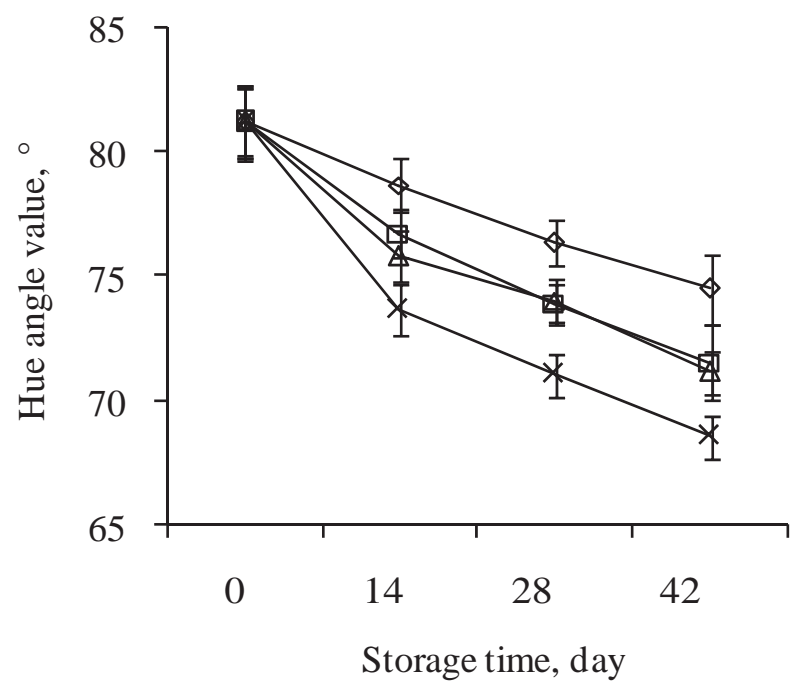

Fig. 3. Hue angle value of apricot treated on different days after harvest during storage at $1{ }^{\circ} \mathrm{C}$ $\left(\diamond: 1-\mathrm{MCP}_{1 \mathrm{st}} ; \square: 1-\mathrm{MCP}_{3 \mathrm{rd}} ; \triangle: 1-\mathrm{MCP}_{5 \text { th }} ; \mathrm{x}\right.$ : Control). Values are the mean $\pm \mathrm{SD}$

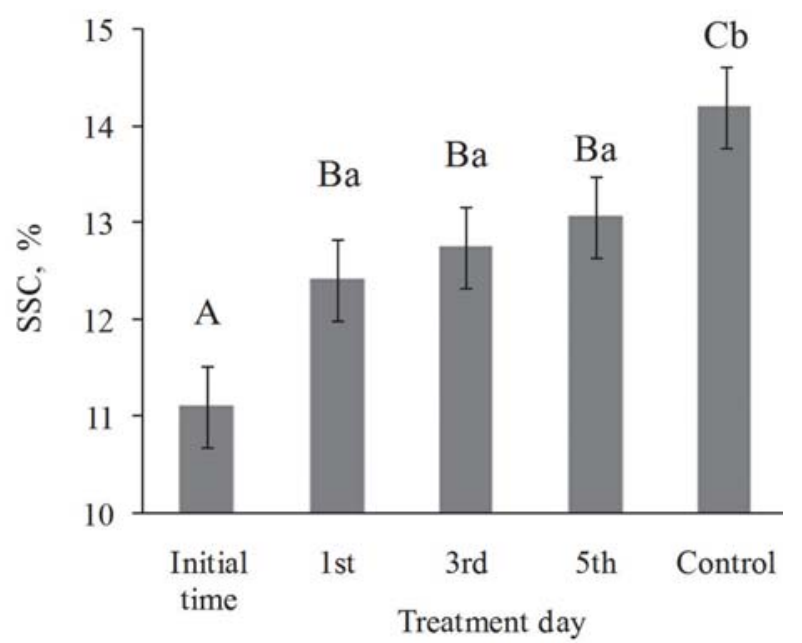

Fig. 4. Soluble solid content of apricot treated on different days after harvest at $42^{\text {nd }}$ day. Values are the mean \pm SD. Upper case is for the comparisons with initial value (Dunnett, $\mathrm{P}<0.05$ ). Lower case is for the comparisons of treatment temperatures (Tukey's, $\mathrm{P}<0.05$ ).

\subsection{Discussion}

Most primary research on 1-MCP application were conducted at ambient temperature. There have been studies reporting that 1-MCP application at cold temperature was not as effective as those carried out at warmer temperatures, and sometimes 1-MCP did not have an effect on 
some crops. It was assumed that the binding between 1-MCP and receptors was low at cold temperatures (MACNISH et al., 2000). For example, 1-MCP treatment at $20{ }^{\circ} \mathrm{C}$ was more effective than at $5{ }^{\circ} \mathrm{C}$ for broccoli (Ku \& Wills, 1999; Able et al., 2002). However, the effectiveness of 1-MCP depends not only on treatment temperature, but also on cultivar, maturity, concentration, and treatment time (WATKINS, 2006). There were several reports about the correlation between treatment period and temperature. DEELL and co-workers (2002) found that corresponding exposure duration of 'Cortland' apples was $6 \mathrm{~h}$ at $23{ }^{\circ} \mathrm{C}$ or $9 \mathrm{~h}$ at $3{ }^{\circ} \mathrm{C}$. Other research also indicated that there was no difference between treatment at $20{ }^{\circ} \mathrm{C}$ and at $0.5^{\circ} \mathrm{C}$ for $24 \mathrm{~h}$ (Watkins \& Nock, 2005). Treatment duration from 12 to $24 \mathrm{~h}$ was enough to maintain the quality of fruit (Blankenship \& Dole, 2003). In this study, 1-MCP strongly affected quality of apricots during cold storage and shelf-life in comparison to control. Most changes in ethylene, $\mathrm{CO}_{2}$ production, firmness, and hue angle values were associated with the duration of storage periods and temperature rather than treatment temperatures and delays of application. However, no significant effect of different treatment temperatures was observed which coincided with the results found for apples (DAUNY \& JOYCE, 2002).

In practice, application could be delayed by several days depending on room loading period. In order to prolong the possible period of filling the storage room, fruit should be cooled rapidly after harvest and then 1-MCP application should be carried out at cold temperature. So, precooling fruit to suitable temperature in order to suppress the ethylene production and 1-MCP treatment at that specific temperature is really necessary. The effect of delayed 1-MCP application on apples was observed (WATKINS \& Nock, 2005). The report indicated that most quality changes were associated with cultivar, storage type and period but not by delayed treatment. Another study showed that 1-MCP treatment on pear could be delayed up to 7 days, although earlier is better (KuBO et al., 2003). Those findings were in agreement with our results.

\section{Conclusions}

This research confirmed that $1-\mathrm{MCP}$ treatment has a potential to delay ripening of the 'Zebra' apricot. There was no significant difference between treatment temperatures on apricot quality during storage and shelf-life. In addition, earlier treatment could extend the storage life of apricot. Application of 1-MCP on the $1^{\text {st }}$ day after harvest showed the highest effectiveness. However, 1-MCP treatment could be postponed till the $5^{\text {th }}$ day after harvest, and the quality of apricot was still acceptable.

We are thankful for the support provided by Rohm and Haas Polska Sp.z.o.o. (Poland).

\section{References}

Able, A.J., Wong, L.S., Prasad, A. \& O'hare, T.J. (2002): 1-MCP is more effective on a floral brassica (Brassica oleracea var. italica L.) than a leafy brassica (Brassica rapa var. chinensis). Postharvest Biol. Tec., 26, 147155.

Blankenship, S.M. \& Dole, J.M. (2003): 1-Methylcyclopropene: a review. Postharvest Biol. Tec., 28, 1-25. 
Dauny, P.T. \& Joyce, D.C. (2002): 1-MCP improves storability of 'Queen Cox' and 'Bramley' apple fruit. HortScience, 37, 1082-1085

DeEll, J.R., Murr, D.P., Porteous, M.D. \& Vasantha Rupasinghe, H.P. (2002): Influence of temperature and duration of 1-methylcyclopropene (1-MCP) treatment on apple quality. Postharvest Biol. Tec., 24, 349-353.

Dong, L., LuRIE, S. \& ZHou, H.-W. (2002): Effect of 1-methylcyclopropene on ripening of 'Canino' apricots and 'Royal Zee' plums. Postharvest Biol. Tec., 24, 135-145.

HitKa, G., Zsom, T., Nguyen, L.P.L. \& Balla, C. (2014): Effect of 1-methylcyclopropene on 'Bosc Kobak' pears. Acta Alimentaria, 43 (Suppl.), 73-77.

Kovács, E., Merész, P., Kristóf, Z. \& Németh-Szerdahelyi, E. (2008): Ripening and microstructure of apricot (Prunus armeniaca L.). Acta Alimentaria, 37, 23-39.

Ku, V.V.V. \& WilLs, R.B.H. (1999): Effect of 1-methylcyclopropene on the storage life of broccoli. Postharvest Biol. Tec., 17, 127-132.

Kubo, Y., Hiwasa, K., Owino, W.O., Nakano, R. \& Inaba, A. (2003): Influence of time and concentration of 1-MCP application on the shelf-life of pear 'La France' fruit. HortScience, 38, 1414-1416.

LecCese, A., BartolinI, S. \& Viti, R. (2008): Total antioxidant capacity and phenolics content in fresh apricots. Acta Alimentaria, 37, 65-76.

Macnish, A., Hofman, P., Joyce, D., Simons, D. \& Reid, M. (2000): 1-Methylcyclopropene treatment efficacy in preventing ethylene perception in banana fruit and grevillea and waxflower flowers. Anim. Prod. Sci, 40, $471-481$.

WATKins, C.B. \& Nock, J.F. (2005): Effects of delays between harvest and 1-methylcyclopropene treatment, and temperature during treatment, on ripening of air-stored and controlled-atmosphere-stored apples. HortScience, 40, 2096-2101.

WATKins, C.B. (2006): The use of 1-methylcyclopropene (1-MCP) on fruits and vegetables. Biotechnol. Adv., 24, 389-409.

Wu, B., Guo, Q., Wang, G.-X., Peng, X.-Y., Wang, J.-D. \& Che, F.-B. (2015): Effects of different postharvest treatments on the physiology and quality of 'Xiaobai' apricots at room temperature. J. Food Sci. Technol., 52, $2247-2255$.

Zsom-Muna, V. \& FelföLdi, J. (2007): Vibration behaviour of long shape vegetables. Progr. Agr. Eng. Sci., 3(1), $21-46$. 